\title{
Prolactin and Autoimmunity
}

\author{
Vânia Vieira Borba ${ }^{1,2,3}$, Gisele Zandman-Goddard ${ }^{3}$ and Yehuda Shoenfeld ${ }^{3,4 *}$ \\ 'Department "A" of Internal Medicine, Coimbra University Hospital Centre, Coimbra, Portugal, ${ }^{2}$ Faculty of Medicine, \\ University of Coimbra, Coimbra, Portugal, ${ }^{3}$ Zabludowicz Center for Autoimmune Diseases, Sheba Medical Center, \\ Tel-Hashomer, Israel, ${ }^{4}$ Sackler Faculty of Medicine, Tel-Aviv University, Tel-Aviv, Israel
}

\section{OPEN ACCESS}

Edited by:

Virginia Rider,

Pittsburg State University,

United States

Reviewed by:

Walter Malorni,

Istituto Superiore di Sanità, Italy

Christoph Baerwald,

Universitätsklinikum Leipzig, Germany

*Correspondence:

Yehuda Shoenfeld

shoenfe/@post.tau.ac.il

Specialty section:

This article was submitted to

Cytokines and Soluble Mediators in

Immunity,

a section of the journal

Frontiers in Immunology

Received: 29 October 2017

Accepted: 11 January 2018

Published: 12 February 2018

Citation:

Borba W, Zandman-Goddard G and Shoenfeld $Y$ (2018)

Prolactin and Autoimmunity.

Front. Immunol. 9:73.

doi: 10.3389/fimmu.2018.00073
The great asymmetry of autoimmune diseases between genders represents one of the most enigmatic observations among the mosaic of autoimmunity. Sex hormones are believed to play a crucial role on this dimorphism. The higher prevalence of autoimmunity among women at childbearing ages, disease onset/relapses during pregnancy, and post-partum are some of the arguments that support this hypothesis. Certainly, motherhood represents one of the most remarkable challenges for the immune system, which not only has to allow for the conceptus, but also has to deal with complex endocrine alterations. Hormonal homeostasis is known to exert a crucial influence in achieving a competent and healthy immune system. Prolactin (PRL) has a bioactive function acting as a hormone and a cytokine. It interferes with immune system modulation, mainly inhibiting the negative selection of autoreactive B lymphocytes. Likewise, hyperprolactinemia has been described in relation to the pathogenesis and activity of several autoimmune disorders. Dopamine is an effective inhibitor of PRL secretion due to either a direct influence on the hypophysis or stimulation of postsynaptic dopamine receptors in the hypothalamus, arousing the release of the PRL inhibitory factor. Hence, dopamine agonists have proven to offer clinical benefits among autoimmune patients and represent a promising therapy to be explored. In this review, we attempt to provide a critical overview of the link between PRL, autoimmune diseases, and motherhood.

Keywords: sex hormones, prolactin, autoimmunity, systemic lupus erythematosus, multiple sclerosis, systemic sclerosis

\section{INTRODUCTION}

Currently, more than 80 autoimmune disorders are recognized, in which aberrant immune responses against self-different organs and tissues play a crucial role (1). Gender dimorphism represents one of the most enigmatic observations among the mosaic of autoimmunity. Susceptibility genes, epigenetic modifications, gender-related composition of gut microbiota, and sex hormones are believed to be a mainstay of this asymmetry $(2,3)$. The greater prevalence of autoimmunity among childbearing age women, disease relapses during pregnancy, and post-partum are some of the arguments that support this hypothesis (4). Indeed, women have enhanced immune reactivity, larger antigen-presenting capability and mitogenic responses, increased antibody production, higher immunoglobulin (Ig) levels, and the ability to reject allografts more rapidly (5). The immune and neuroendocrine system

Abbreviations: IFN, interferon; Ig, immunoglobulin; IL, interleukin; MAPK, mitogen-activated protein kinase; MHC, major histocompatibility complex; PRL, prolactin; PRLR, prolactin receptor; Th, T helper cells; TNF, Tumor necrosis factor; Treg, T regulatory cells; STAT1, Signal transducer and activator of transcription 1. 
are intimately connected, partaking of dynamic bidirectional communication. Prolactin (PRL) has a recognized immunestimulatory effect, specially inhibiting the negative selection of autoreactive B lymphocytes, promoting autoimmunity. In accordance, hyperprolactinemia has been associated with several autoimmune diseases, influencing its pathogenesis (6). Although the mechanisms involving this interaction are not completely understood, it has been documented that PRL can influence the communication and regulation of immune cells (7).

\section{PRL, THE HORMONE, AND THE CYTOKINE}

Prolactin is a $23-\mathrm{kD}$ peptide hormone secreted in the pituitary gland, through the hypothalamic-pituitary-adrenal axis, under tonic inhibition of dopamine. Interestingly, this hormone can also be produced in extra-pituitary locations, such as decidua, ovary, prostate, mammary gland, adipose tissue, brain, and immune cells. When produced in extra-pituitary sites, PRL has different molecular weight and bioactivity. Hyperprolactinemia is usually defined as fasting levels of above $20 \mathrm{ng} / \mathrm{ml}$ in men and above $25 \mathrm{ng} / \mathrm{ml}$ in women (8). The expected rate among healthy population is up to $3 \%$. Levels physiologically increase during lactation, but also as result of several diseases, including prolactinoma, hypothyroidism, and adrenal insufficiency (9). Besides, PRL secretion is regulated by cytokines such as interleukin (IL)-1, IL-2, and IL-6, which are stimulators, while endothelin-3 and interferon (IFN)- $\gamma$ play an inhibitory role. This hormone can be found adopting several isoforms due to variations in posttranslational modifications (10). The three main isoforms are the monomeric (free little PRL), big PRL, and macroprolactin (big big). The most biologically potent isoform is the monomeric free (little) PRL, which consists of 199 amino acids and has a molecular weight of $23 \mathrm{kDa}$ (11). The PRL receptor is a member of the type 1 cytokine/hematopoietic receptor superfamily and is widely expressed through the immune system, including monocytes, lymphocytes, macrophages, natural killer cells, granulocytes, and thymic epithelial cells (12). Hence, the binding of PRL to its receptor activates downstream signaling pathways that will manipulate immune cells proliferation, differentiation, secretion, and survival $(13,14)$. This molecule is an integral member of the immune-neuroendocrinology network and has been largely associated with autoimmune diseases (15).

\section{PRL and Immune Modulation}

Prolactin strongly persuades the innate and adaptive immune responses, managing the maturation of $\mathrm{CD} 4-\mathrm{CD} 8$ - thymocytes to CD4+ CD8+ T cells, through IL-2 receptor expression (16, 17). A direct correlation between PRL levels and the number of B and CD4+ T lymphocytes has been reported (18). Indeed, hyperprolactinemia can impair B-cell clonal deletion, deregulate receptor editing and diminish the threshold for activation of B cells, promoting auto-reactivity (19-21). It is capable of changing Th1 and Th2 type cytokine production, promoting IL- 6 and INF- $\gamma$ secretion, and playing a regulatory role on IL-2 levels (22, 23). Furthermore, PRL increases Ig production, stimulates the development of antigen-presenting cells expressing major histocompatibility complex class II, and upholds the co-stimulatory molecules CD86, CD80, and CD40 (24). Interestingly, assorted autoantibodies, including anti-cardiolipin, anti-PRL, anti-La, anti-Ro, among others, were detected in patients with hyperprolactinemia (25-27). Finally, PRL has been shown to influence dendritic cells to skew antigen presentation to pro-inflammatory function phenotype, enhancing IFN- $\alpha$ production (28). During pregnancy, one of the most decisive immunologic adaptations is the shift from a Th1/Th17 pro-inflammatory response toward a Th2/T regulatory cell (Treg) response, which promotes tolerance and inhibits natural killer cells cytotoxicity $(2,29)$. In accordance, differences in the activity of assorted autoimmune diseases have been reported during pregnancy and post-partum. For a better comprehension, the effects of PRL on the immune system cells were summarized in Table $\mathbf{1}$.

\section{PRL during Pregnancy and Breastfeeding}

Sex hormones can influence different functions on the immune system network. Typically, PRL and estrogens act as immune stimulants, while progesterone and testosterone exert a suppressive role $(51,52)$. Pregnancy inspires unique changes in endocrine and immune signaling, in order to tolerate and support the development and survival of the placenta and fetus in the hostile maternal immune system environment. PRL levels increase during pregnancy and reach peak values during delivery (53). Suckling stimulates the nerve endings in the nipple-areolar complex and strongly promotes hormone production. A large study performed by Stuebe et al. (54) evaluated PRL levels in women who exclusively breastfed their infants. The authors successfully reported wide changing baseline values (from $9 \mathrm{ng} / \mathrm{dl}$ before to $74 \mathrm{ng} / \mathrm{dl} 10 \mathrm{~min}$ after breastfeeding), depending on the frequency of feedings (54). In accordance, during the pregnancy and lactation period, several patients experience disease onset or relapse, suggesting an active influence of PRL. Indeed, a significant association between PRL levels and disease activity was found in systemic lupus erythematosus (55), rheumatoid arthritis (50, $56)$, and peripartum cardiomyopathy patients $(57,58)$, therefore breastfeeding should not be encouraged among those patients.

\section{PRL and the Role of Dopamine Agonists}

Dopamine is an effective inhibitor of PRL secretion due either a direct influence on the hypophysis or stimulation of postsynaptic dopamine receptors in the hypothalamus, arousing the release of the PRL inhibitory factor. Bromocriptine is an ergot alkaloid that binds to the dopamine receptor and inhibits the central synthesis of PRL. In addition, this drug can also influence T and B lymphocytes through the dopamine receptor $(59,60)$. Bromocriptine has been shown to decrease autoantibodies production, influence lymphocyte function and modulate the expression of surface molecules. By contrast, it exerts no clear effect on extra-pituitary PRL production. In conclusion, the beneficial therapeutic effects in murine and human trials, and the low toxicity of the drug outline a solid rationale for its attempt in future therapeutic proposals (61). 
TABLE 1 | Effects of prolactin (PRL) on the immune system cells.

\begin{tabular}{|c|c|c|c|c|}
\hline $\begin{array}{l}\text { Immune } \\
\text { cells }\end{array}$ & $\begin{array}{l}\text { PRL } \\
\text { secretion }\end{array}$ & $\begin{array}{l}\text { Prolactin } \\
\text { receptor } \\
\text { (PRLR) } \\
\text { expression }\end{array}$ & Immunological effects of PRL & Reference \\
\hline Thymocytes & $\checkmark$ & $\checkmark$ & $\begin{array}{l}\text { - Promote the differentiation of CD4-CD8- thymocytes into CD4+ CD8+ cells } \\
\text { - Regulate the maintenance of thymocyte viability during differentiation }\end{array}$ & $(30,31)$ \\
\hline Dendritic cells & $?$ & $\checkmark$ & $\begin{array}{l}\text { - Enhance the production of cytokines (IL-12, TNF- } \alpha, \mathrm{IL}-1 \beta \text { ) } \\
\text { - Increase the responsiveness in allogeneic mixed leukocyte reactions (upregulation of MHC surface expression } \\
\text { and the co-stimulatory molecule CD80) }\end{array}$ & $(32,33)$ \\
\hline T cells & $\checkmark$ & $\checkmark$ & $\begin{array}{l}\text { - Exert an immunomodulatory role at early stages of T-cell activation } \\
\text { - Increase secretion of TNF- } \alpha \text {, IFN- } \gamma \text {, and IL-2 } \\
\text { - Trigger the IL-2-stimulated proliferation } \\
\text { - Promote dysfunction of regulatory T cells } \\
\text { - Enhance adhesion to endothelial cells }\end{array}$ & $(34-37)$ \\
\hline B cells & $\checkmark$ & $\checkmark$ & $\begin{array}{l}\text { - Influence B-cell maturation process, promoting the survival of self-reactive clones } \\
\text { - Increase the viability of immature B cells by rescuing them from apoptosis }\end{array}$ & $(38,39)$ \\
\hline $\begin{array}{l}\text { Natural killer } \\
\text { cells }\end{array}$ & $?$ & $\checkmark$ & $\begin{array}{l}\text { - Induce natural killer cells differentiation to PRL-activated killer cells (PAK cells) in a dose-dependent way } \\
\text { - Interfere with proliferation and cytotoxic activity } \\
\text { - Promote the release of IFN- } \gamma\end{array}$ & $(40-42)$ \\
\hline Monocytes & $\checkmark$ & $\checkmark$ & - Increase TNF expression & $(43-45)$ \\
\hline Granulocytes & $?$ & $\checkmark$ & $\begin{array}{l}\text { - Activate the STAT1 and MAPK pathways } \\
\text { - Contribute for the transcription of IRF-1 and iNOS }\end{array}$ & $(46,47)$ \\
\hline Macrophages & $\checkmark$ & $\checkmark$ & $\begin{array}{l}\text { - Cooperate with other pro-inflammatory stimuli to activate macrophages via engagement with the PRLR } \\
\text { - Promote the secretion of chemokines and cytokines (IL-1 } \beta, I L-12 \beta \text {, IFN- } \gamma \text {, and TNF) }\end{array}$ & $(7,48-50)$ \\
\hline
\end{tabular}

iNOS: inducible nitric oxide synthase; IFN, interferon; IL, interleukin; IRF-1, interferon regulatory factor 1; MAPK, mitogen-activated protein kinase; MHC, major histocompatibility complex; STAT1, signal transducer and activator of transcription 1; TNF, tumor necrosis factor.

\section{HYPERPROLACTINEMIA AND AUTOIMMUNE DISEASES}

Hyperprolactinemia has been reported in patients with several autoimmune diseases, commonly manipulating disease development and perpetuation (62). The link between PRL and autoimmunity has been proposed to have a genetic background $(63,64)$. The PRL gene is located on the short arm of chromosome 6, near the HLA-DRB1 region, which is known for its association with assorted immune-mediated disorders (65).

\section{PRL and Systemic Lupus Erythematosus}

Systemic lupus erythematosus is an autoimmune disease, typically affecting young women at reproductive age (66). Hyperprolactinemia has been reported in a wide range of lupus patients from both genders (15-33\%). In accordance, PRL levels have shown direct correlation with clinical and serological disease activity (16, 67-69). Results from several trials report also an association with neurological, renal and hematological involvement, serositis, enhanced anti-double-stranded DNA antibodies, and diminished complement $(70,71)$. Furthermore, PRL bolsters the development of lupus-like phenotype in non-prone mice and exacerbated the disease in a lupus murine experimental study (72). During pregnancy, hyperprolactinemia has been associated with lupus anticoagulant, disease activity, and poor outcomes for mother and fetus (73). In accordance, the presence of anti-PRL antibodies was correlated with lower disease activity and better outcomes in pregnant patients $(74,75)$. The treatment of pregnant women with bromocriptine was shown to prevent disease relapses, improve outcomes, and reduce the doses of concomitant steroidal therapy $(76,77)$. In conclusion, the evidence strongly supports the role of PRL in the pathogenesis and activity of systemic lupus erythematosus.

\section{PRL and Anti-Phospholipid Syndrome}

Anti-phospholipid syndrome is a systemic autoimmune condition, characterized by thrombotic events and/or pregnancy morbidity in the presence of anti-phospholipid antibodies. Hyperprolactinemia was detected in $12 \%$ of patients with antiphospholipid syndrome, with no differences among genders or disease subtypes. Likewise, hormone levels were shown to be correlated with the presence of lupus anticoagulants, intrauterine growth retardation, and miscarriages among pregnant patients (78). By contrast, no significant correlation was found with thrombotic events, although PRL was recently proposed as a novel risk factor for thrombotic disease, since it acts as a potent platelet aggregation co-activator (79-82). Previously, bromocriptine was tested in animal models with anti-phospholipid syndrome and lupus, showing a suppressive effect on both diseases, probably through induction of natural non-specific CD8 suppressor cells (59).

\section{PRL and Rheumatoid Arthritis}

Rheumatoid arthritis is a chronic autoimmune disease that if untreated leads to progressive and irreversible destruction of cartilage and bone. The relationship between PRL and rheumatoid arthritis emerged from the adjacent location of the human PRL gene and HLA region (16). Recent studies reported higher levels of PRL in serum and synovial fluid of patients with rheumatoid arthritis. This suggests increased production, either systemic or locally secreted by immune cells, in putative relation with disease activity $(45,56)$. Pregnant women with 
rheumatoid arthritis, due to a transient period of hypercortisolism, experience disease improvement. After delivery, flares are frequently reported (83). Women who breastfeed after the first pregnancy have a higher risk of developing rheumatoid arthritis, suggesting an active influence from PRL $(84,85)$. In addition, nearly $90 \%$ of these women will relapse within the first 3 months of postpartum and almost all patients will flair within the next 9 months. Indeed, severe disease was associated with longer breastfeeding periods and higher number of breast fed children. In animal models, bromocriptine was able to suppress postpartum exacerbation of collagen-induced arthritis (86). In humans, the treatment with bromocriptine revealed controversial findings $(87,88)$, probably because bromocriptine does not influence lymphocyte-derived PRL production (89). Hence, systemic and locally produced PRL may offer distinct contributions to inflammatory arthritis.

\section{PRL and Systemic Sclerosis}

Systemic sclerosis is a connective tissue disease characterized by alterations of the microvasculature, disturbances of the immune system, and massive deposition of collagen and other matrix substances in the skin and internal organs (90). High levels of PRL have been reported in $13-59 \%$ of patients with systemic sclerosis (91). Likewise, a significant correlation between hormone levels and the severity of skin sclerosis, lung, and cardiovascular involvement was found (92-94). The sources of PRL in this disease are believed to reside on enhanced lymphocytic secretion, increased dopaminergic central tone, and drug-induction, mainly by antidepressants and prokinetics (95). Pregnancy per se does not exacerbate the disease, even though cases have been reported of women with organ insufficiency mainly pulmonary hypertension and severe skin fibrosis (96, 97). Patients with disease duration of less than 4 years, with diffuse cutaneous subtype, presence of anti-RNA polymerase III or anti-topoisomerase I antibodies are at higher risk for obstetric complications and should delay pregnancy until the disease is quiescent (98). In conclusion, PRL was found to be correlated with disease severity and activity.

\section{PRL and Multiple Sclerosis}

Multiple sclerosis is a chronic inflammatory disorder involving the central nervous system $(99,100)$. In animal models, it is represented by experimental autoimmune encephalomyelitis, believed to be an inflammatory response against oligodendrocytes that form myelin sheaths surrounding neuronal axon driven by myelin-reactive CD4+ Th1/Th17 cells (101). Several studies reported a positive correlation between hyperprolactinemia and disease onset, relapse, and number of anti-myelin oligodendrocyte glycoprotein antibody secreting cells (102, 103). Indeed, the source of high PRL levels among those patients is unclear, albeit observations suggest that it may be part of a non-specific hypothalamic-pituitary-adrenal axis dysregulation due to neurodegeneration and/or demyelination (104). Currently, PRL is believed to have a dual impact in the central nervous system. On the one hand, PRL might support system repair by providing regenerative signals for neurons, oligodendrocytes, and adult neural stem/progenitor cells. On the other hand, its stimulation of peripheral immune cells might promote aberrant immune responses and negatively impact the disease $(105,106)$. Typically, pregnancies were believed to have a negative impact in women with multiple sclerosis, provoking postpartum exacerbations and increasing permanent disability (107). Nowadays, it is known that the risk of relapse significantly declines during the third trimester of pregnancy and increases three-fold in the first 3-4 months after delivery, with no references about medication consumption or breastfeeding options (108). Recently, studies revealed that an earlier return of menses was associated with a higher risk of disease relapse in the first 6 months after delivery, which suggests a natural protection from exclusive breastfeeding (109). Likewise, prolonged lactational amenorrhea was correlated with a lower risk of postpartum relapses (110). In conclusion, evidence supports a plausible protection from exclusive breastfeeding, although no studies have examined the long-term effects of breastfeeding, particularly in exclusive patterns.

\section{PRL and Celiac Disease}

Celiac disease is a gluten-sensitive autoimmune enteropathy where both adaptive immunity and innate immunity are involved in its development (111). Serum PRL levels were positively correlated with disease activity, degree of mucosal atrophy, and with the serum concentration of anti-endomysial antibodies. Recently, a longitudinal study revealed diminished levels of PRL after 6 months following a gluten-free diet. The evidence of decreasing PRL simultaneously with the decline of anti-transglutaminase antibodies suggests a direct connection with a gluten-free diet and hormone levels (112).

\section{PRL and Autoimmune Thyroid Disease}

Autoimmune thyroid diseases comprise mainly two disorders, Grave's disease and Hashimoto thyroiditis (113). Hyperprolactinemia was found in $20 \%$ of patients with autoimmune thyroid disease and had double the frequency among hypothyroidism patients. Around $90 \%$ of Hashimoto's thyroiditis patients presented significantly higher PRL levels in association with decreased cortisol titers (114). The role of dopamine agonists in the treatment of autoimmune thyroid disease is yet to be determined.

\section{PRL and Peripartum Cardiomyopathy}

Peripartum cardiomyopathy is a congestive heart failure occurring in the last month of pregnancy or 5 months after delivery, in the absence of preexisting heart disease (115). The etiology of this disease remains unclear, although plausible causes have been proposed, such as nutritional deficiency, viral infections, stress-activated cytokines, pathological response to hemodynamic stress, inflammation, and autoimmune reactions (116). Evidence supports an active role of PRL in the pathophysiology of this disease. Increased oxidative stress leads to subsequent $16-\mathrm{kDa}$ PRL production, impairing the cardiac vasculature and its metabolism, culminating in systolic heart failure $(117,118)$. Interestingly, the presence of autoantibodies against sarcomeric myosin and troponin I were detected among women with peripartum myocardiopathy, suggesting the presence of an underlying autoimmune disorder. In addition, these antibodies were associated with the severity of left ventricle dysfunction and 
lower rate of full cardiac recovery on follow-up (119). Interestingly, patients demonstrated an abnormal cytokine profile (increased levels of TNF, IL-6 and soluble Fas receptors), decreased levels of CD4+ CD25lo Tregs, a heightened level of fetal microchimerism, and a significant reduction in the plasma levels of progesterone, estradiol, and relaxin, contributing to abnormal immune responses and inflammatory processes $(120,121)$. Recently, dopamine agonists have shown promising results in the treatment of this disease, dramatically improving outcomes $(58,122-124)$. The 2010 European position statement does not encourage breastfeeding based on concerns regarding the perpetuation of PRL pathways (125).

\section{CONCLUSION}

The dimorphism between genders in autoimmune diseases is believed to rely on sexhormones. PRL exerts a great influence in immune system modulation, mainly inhibiting the negative selection of autoreactive B lymphocytes and has been associated with the pathogenesis of several autoimmune disorders. During pregnancy and the lactation period, assorted autoimmune patients experience disease relapse, suggesting an active influence of PRL. Immunological studies of pregnant and postpartum women with autoimmune diseases offer a biologically rich opportunity to improve our understanding of the hormonal impact on disease relapse pathophysiology. Although the interest on the relationship between PRL, immune modulation, and autoimmune diseases

\section{REFERENCES}

1. Perricone R, Perricone C, Shoenfeld Y. Autoimmunity: when the immune system becomes the self-ish giant. Autoimmun Rev (2011) 10(10):575-6. doi:10.1016/j.autrev.2011.05.003

2. Ortona E, Pierdominici M, Maselli A, Veroni C, Aloisi F, Shoenfeld Y. Sex-based differences in autoimmune diseases. Ann Ist Super Sanita (2016) 52(2):205-12. doi:10.4415/ann_16_02_12

3. Krasselt M, Baerwald C. Sex, symptom severity, and quality of life in rheumatology. Clin Rev Allergy Immunol (2017) 11:1-16. doi:10.1007/ s12016-017-8631-6

4. Orbach H, Shoenfeld Y. Hyperprolactinemia and autoimmune diseases. Autoimmun Rev (2007) 6(8):537-42. doi:10.1016/j.autrev.2006.10.005

5. Zandman-Goddard G, Peeva E, Shoenfeld Y. Gender and autoimmunity. Autoimmun Rev (2007) 6(6):366-72. doi:10.1016/j.autrev.2006.10.001

6. Buskila D, Sukenik S, Shoenfeld Y. The possible role of prolactin in autoimmunity. Am J Reprod Immunol (1991) 26(3):118-23. doi:10.111 1/j.1600-0897.1991.tb00708.x

7. Tang MW, Garcia S, Gerlag DM, Tak PP, Reedquist KA. Insight into the endocrine system and the immune system: a review of the inflammatory role of prolactin in rheumatoid arthritis and psoriatic arthritis. Front Immunol (2017) 8:720. doi:10.3389/fimmu.2017.00720

8. Majumdar A, Mangal NS. Hyperprolactinemia. J Hum Reprod Sci (2013) 6(3):168-75. doi:10.4103/0974-1208.121400

9. Savino W. Prolactin: an immunomodulator in health and disease. Front Horm Res (2017) 48:69-75. doi:10.1159/000452906

10. Devi YS, Halperin J. Reproductive actions of prolactin mediated through short and long receptor isoforms. Mol Cell Endocrinol (2014) 382(1):400-10. doi:10.1016/j.mce.2013.09.016

11. Marcotegui AR, Garcia-Calvo A. [Biochemical diagnosis of monomeric hyperprolactinemia]. An Sist Sanit Navar (2011) 34(2):145-52. doi:10.4321/ S1137-66272011000200002

12. Orbach H, Zandman-Goddard G, Amital H, Barak V, Szekanecz Z, Szucs $\mathrm{G}$, et al. Novel biomarkers in autoimmune diseases: prolactin, ferritin, vitamin D, and TPA levels in autoimmune diseases. Ann N Y Acad Sci (2007) 1109:385-400. doi:10.1196/annals.1398.044 has emerged in the past few years, more studies are required to further delineate the influence of PRL in autoimmune disease. Eventually, gut microbiome, immune cells transcriptome, and proteome might be the answers to those questions being unsolved to date.

\section{Highlights}

- Susceptibility genes, epigenetic modifications, microbiome, and sex hormones are believed to be a mainstay of the gender asymmetry in autoimmune diseases.

- PRL influences the negative selection of autoreactive B cells, promoting their proliferation, survival, and antibody production.

- Hyperprolactinemia has been associated with several autoimmune diseases and is believed to play a crucial role in their pathogenesis.

- A significant association between PRL and disease flairs was found in systemic lupus erythematosus and rheumatoid arthritis.

- Dopamine agonists have been used in the treatment of many autoimmune diseases with great benefits.

\section{AUTHOR CONTRIBUTIONS}

VB, ZG, and YS contributed equally to the construction of this review.

13. Thoreau E, Petridou B, Kelly PA, Djiane J, Mornon JP. Structural symmetry of the extracellular domain of the cytokine/growth hormone/prolactin receptor family and interferon receptors revealed by hydrophobic cluster analysis. FEBS Lett (1991) 282(1):26-31. doi:10.1016/0014-5793(91) 80437-8

14. Jeganathan V, Peeva E, Diamond B. Hormonal milieu at time of B cell activation controls duration of autoantibody response. J Autoimmun (2014) 53:46-54. doi:10.1016/j.jaut.2014.02.007

15. Anaya JM, Shoenfeld Y. Multiple autoimmune disease in a patient with hyperprolactinemia. Isr Med Assoc J (2005) 7(11):740-1.

16. Vera-Lastra O, Jara LJ, Espinoza LR. Prolactin and autoimmunity. Autoimmun $\operatorname{Rev}(2002)$ 1(6):360-4. doi:10.1016/S1568-9972(02)00081-2

17. Pereira Suarez AL, Lopez-Rincon G, Martinez Neri PA, Estrada-Chavez C. Prolactin in inflammatory response. Adv Exp Med Biol (2015) 846:243-64. doi:10.1007/978-3-319-12114-7_11

18. Brand JM, Frohn C, Cziupka K, Brockmann C, Kirchner H, Luhm J. Prolactin triggers pro-inflammatory immune responses in peripheral immune cells. Eur Cytokine Netw (2004) 15(2):99-104.

19. Buckley AR. Prolactin, a lymphocyte growth and survival factor. Lupus (2001) 10(10):684-90. doi:10.1191/096120301717164912

20. Kochendoerfer SK, Krishnan N, Buckley DJ, Buckley AR. Prolactin regulation of Bcl-2 family members: increased expression of bcl-xL but not mcl-1 or bad in Nb2-T cells. J Endocrinol (2003) 178(2):265-73. doi:10.1677/ joe. 0.1780265

21. Saha S, Gonzalez J, Rosenfeld G, Keiser H, Peeva E. Prolactin alters the mechanisms of B cell tolerance induction. Arthritis Rheum (2009) 60(6):1743-52. doi:10.1002/art.24500

22. Tomio A, Schust DJ, Kawana K, Yasugi T, Kawana Y, Mahalingaiah S, et al. Prolactin can modulate CD4+ T-cell response through receptor-mediated alterations in the expression of T-bet. Immunol Cell Biol (2008) 86(7):616-21. doi: $10.1038 /$ icb. 2008.29

23. Mackern-Oberti JP, Jara EL, Riedel CA, Kalergis AM. Hormonal modulation of dendritic cells differentiation, maturation and function: implications for the initiation and progress of systemic autoimmunity. Arch Immunol Ther Exp (Warsz) (2017) 65(2):123-36. doi:10.1007/s00005-0160418-6 
24. Peeva E, Zouali M. Spotlight on the role of hormonal factors in the emergence of autoreactive B-lymphocytes. Immunol Lett (2005) 101(2):123-43. doi:10.1016/j.imlet.2005.05.014

25. Buskila D, Berezin M, Gur H, Lin HC, Alosachie I, Terryberry JW, et al. Autoantibody profile in the sera of women with hyperprolactinemia. J Autoimmun (1995) 8(3):415-24. doi:10.1006/jaut.1995.0033

26. Krause I, Blumenfeld Z, Malchinsky M, Cohen S, Blank M, Eldor A, et al. Anti-endothelial cell antibodies in the sera of hyperprolactinemic women. Lupus (1998) 7(6):377-82. doi:10.1191/096120398678920316

27. De Bellis A, Colao A, Pivonello R, Savoia A, Battaglia M, Ruocco G, et al. Antipituitary antibodies in idiopathic hyperprolactinemic patients. Ann N Y Acad Sci (2007) 1107:129-35. doi:10.1196/annals.1381.014

28. Matera L, Mori M, Galetto A. Effect of prolactin on the antigen presenting function of monocyte-derived dendritic cells. Lupus (2001) 10(10):728-34. doi:10.1191/096120301717164967

29. Borchers AT, Naguwa SM, Keen CL, Gershwin ME. The implications of autoimmunity and pregnancy. J Autoimmun (2010) 34(3):J287-99. doi:10.1016/j. jaut.2009.11.015

30. Gagnerault MC, Touraine P, Savino W, Kelly PA, Dardenne M. Expression of prolactin receptors in murine lymphoid cells in normal and autoimmune situations. J Immunol (1993) 150(12):5673-81.

31. Lepletier A, de Carvalho VF, Rodrigues e Silva PM, Villar S, Perez AR, Savino W, et al. Trypanosoma cruzi disrupts thymic homeostasis by altering intrathymic and systemic stress-related endocrine circuitries. PLoS Negl Trop Dis (2013) 7(11):e2470. doi:10.1371/journal.pntd.0002470

32. Carreno PC, Jimenez E, Sacedon R, Vicente A, Zapata AG. Prolactin stimulates maturation and function of rat thymic dendritic cells. J Neuroimmunol (2004) 153(1-2):83-90. doi:10.1016/j.jneuroim.2004.04.020

33. Jara LJ, Benitez G, Medina G. Prolactin, dendritic cells, and systemic lupus erythematosus. Autoimmun Rev (2008) 7(3):251-5. doi:10.1016/j. autrev.2007.11.018

34. Dimitrov S, Lange T, Fehm HL, Born J. A regulatory role of prolactin, growth hormone, and corticosteroids for human T-cell production of cytokines. Brain Behav Immun (2004) 18(4):368-74. doi:10.1016/j.bbi.2003.09.014

35. Carreno PC, Sacedon R, Jimenez E, Vicente A, Zapata AG. Prolactin affects both survival and differentiation of T-cell progenitors. J Neuroimmunol (2005) 160(1-2):135-45. doi:10.1016/j.jneuroim.2004.11.008

36. Xu D, Lin L, Lin X, Huang Z, Lei Z. Immunoregulation of autocrine prolactin: suppressing the expression of costimulatory molecules and cytokines in T lymphocytes by prolactin receptor knockdown. Cell Immunol (2010) 263(1):71-8. doi:10.1016/j.cellimm.2010.02.018

37. Wu W, Sun M, Zhang HP, Chen T, Wu R, Liu C, et al. Prolactin mediates psychological stress-induced dysfunction of regulatory $\mathrm{T}$ cells to facilitate intestinal inflammation. Gut (2014) 63(12):1883-92. doi:10.1136/ gutjnl-2013-306083

38. Legorreta-Haquet MV, Flores-Fernandez R, Blanco-Favela F, Fuentes-Panana EM, Chavez-Sanchez L, Hernandez-Gonzalez R, et al. Prolactin levels correlate with abnormal B cell maturation in MRL and MRL/lpr mouse models of systemic lupus erythematosus-like disease. Clin Dev Immunol (2013) 2013:287469. doi:10.1155/2013/287469

39. Flores-Fernandez R, Blanco-Favela F, Fuentes-Panana EM, Chavez-Sanchez L, Gorocica-Rosete P, Pizana-Venegas A, et al. Prolactin rescues immature B-cells from apoptosis induced by B-cell receptor cross-linking. J Immunol Res (2016) 2016:3219017. doi:10.1155/2016/3219017

40. Jara LJ, Lavalle C, Fraga A, Gomez-Sanchez C, Silveira LH, MartinezOsuna P, et al. Prolactin, immunoregulation, and autoimmune diseases. Semin Arthritis Rheum (1991) 20(5):273-84. doi:10.1016/0049-0172(91) 90028-X

41. Matera L, Buttiglieri S, Moro F, Geuna M. Effect of prolactin on natural killer and MHC-restricted cytotoxic cells. In: Matera L, Rapaport R, editors. NeuroImmune Biology. (Vol. 2), London: Elsevier (2002). p. 205-18.

42. Mavoungou E, Bouyou-Akotet MK, Kremsner PG. Effects of prolactin and cortisol on natural killer (NK) cell surface expression and function of human natural cytotoxicity receptors (NKp46, NKp44 and NKp30). Clin Exp Immunol (2005) 139(2):287-96. doi:10.1111/j.1365-2249.2004.02686.x

43. Matera L. Endocrine, paracrine and autocrine actions of prolactin on immune cells. Life Sci (1996) 59(8):599-614. doi:10.1016/0024-3205(96)00225-1

44. Tang C, Li Y, Lin X, Ye J, Li W, He Z, et al. Prolactin increases tumor necrosis factor alpha expression in peripheral CD14 monocytes of patients with rheumatoid arthritis. Cell Immunol (2014) 290(1):164-8. doi:10.1016/j. cellimm.2014.06.005

45. Tang MW, Reedquist KA, Garcia S, Gerlag DM, Tak PP. 1.57 Prolactin is locally produced in the synovium of patients with inflammatory arthritic diseases and promotes macrophage activation. Ann Rheum Dis (2014) 73(Suppl 1):A24. doi:10.1136/annrheumdis-2013-205124.56

46. Matera L, Galetto A, Geuna M, Vekemans K, Ricotti E, Contarini M, et al. Individual and combined effect of granulocyte-macrophage colony-stimulating factor and prolactin on maturation of dendritic cells from blood monocytes under serum-free conditions. Immunology (2000) 100(1):29-36. doi:10.1046/j.1365-2567.2000.00996.x

47. Dogusan Z, Hooghe R, Verdood P, Hooghe-Peters EL. Cytokine-like effects of prolactin in human mononuclear and polymorphonuclear leukocytes. J Neuroimmunol (2001) 120(1):58-66. doi:10.1016/S0165-5728(01)00420-9

48. Tripathi A, Sodhi A. Prolactin-induced production of cytokines in macrophages in vitro involves JAK/STAT and JNK MAPK pathways. Int Immunol (2008) 20(3):327-36. doi:10.1093/intimm/dxm145

49. Carvalho-Freitas MI, Anselmo-Franci JA, Palermo-Neto J, Felicio LF. Prior reproductive experience alters prolactin-induced macrophage responses in pregnant rats. J Reprod Immunol (2013) 99(1-2):54-61. doi:10.1016/j. jri.2013.03.005

50. Tang MW, Garcia S, Malvar Fernandez B, Gerlag DM, Tak PP, Reedquist KA. Rheumatoid arthritis and psoriatic arthritis synovial fluids stimulate prolactin production by macrophages. J Leukoc Biol (2017) 102(3):897-904. doi:10.1189/jlb.2A0317-115RR

51. Carp HJ, Selmi C, Shoenfeld Y. The autoimmune bases of infertility and pregnancy loss. J Autoimmun (2012) 38(2-3):J266-74. doi:10.1016/j. jaut.2011.11.016

52. Tan IJ, Peeva E, Zandman-Goddard G. Hormonal modulation of the immune system - a spotlight on the role of progestogens. Autoimmun Rev (2015) 14(6):536-42. doi:10.1016/j.autrev.2015.02.004

53. Zhang F, Xia H, Shen M, Li X, Qin L, Gu H, et al. Are prolactin levels linked to suction pressure? Breastfeed Med (2016) 11:461-8. doi:10.1089/ bfm.2015.0083

54. Stuebe AM, Meltzer-Brody S, Pearson B, Pedersen C, Grewen K. Maternal neuroendocrine serum levels in exclusively breastfeeding mothers. Breastfeed Med (2015) 10(4):197-202. doi:10.1089/bfm.2014.0164

55. Song GG, Lee YH. Circulating prolactin level in systemic lupus erythematosus and its correlation with disease activity: a meta-analysis. Lupus (2017) 26(12):1260-8. doi:10.1177/0961203317693094

56. Fojtikova M, Tomasova Studynkova J, Filkova M, Lacinova Z, Gatterova J, Pavelka K, et al. Elevated prolactin levels in patients with rheumatoid arthritis: association with disease activity and structural damage. Clin Exp Rheumatol (2010) 28(6):849-54.

57. Hilfiker-Kleiner D, Kaminski K, Podewski E, Bonda T, Schaefer A, Sliwa $\mathrm{K}$, et al. A cathepsin $\mathrm{D}$-cleaved $16 \mathrm{kDa}$ form of prolactin mediates postpartum cardiomyopathy. Cell (2007) 128(3):589-600. doi:10.1016/j.cell. 2006.12.036

58. Hilfiker-Kleiner D, Haghikia A, Berliner D, Vogel-Claussen J, Schwab J, Franke A, et al. Bromocriptine for the treatment of peripartum cardiomyopathy: a multicentre randomized study. Eur Heart J (2017) 38(35):2671-9. doi:10.1093/eurheartj/ehx355

59. Blank M, Krause I, Buskila D, Teitelbaum D, Kopolovic J, Afek A, et al. Bromocriptine immunomodulation of experimental SLE and primary antiphospholipid syndrome via induction of nonspecific T suppressor cells. Cell Immunol (1995) 162(1):114-22. doi:10.1006/cimm.1995.1058

60. McMurray RW. Bromocriptine in rheumatic and autoimmune diseases. Semin Arthritis Rheum (2001) 31(1):21-32. doi:10.1053/sarh.2001.25482

61. Buskila D, Shoenfeld Y. Prolactin, bromocriptine and autoimmune diseases. Isr J Med Sci (1996) 32(1):23-7.

62. Shelly S, Boaz M, Orbach H. Prolactin and autoimmunity. Autoimmun Rev (2012) 11(6-7):A465-70. doi:10.1016/j.autrev.2011.11.009

63. Parada-Turska J, Targonska-Stepniak B, Majdan M. [Prolactin in connective tissue diseases]. Postepy Hig Med Dosw (Online) (2006) 60:278-85.

64. Arango MT, Perricone C, Kivity S, Cipriano E, Ceccarelli F, Valesini G, et al. HLA-DRB1 the notorious gene in the mosaic of autoimmunity. Immunol Res (2017) 65(1):82-98. doi:10.1007/s12026-016-8817-7

65. Viatte S, Massey J, Bowes J, Duffus K, Eyre S, Barton A, et al. Replication of associations of genetic loci outside the HLA region with susceptibility 
to anti-cyclic citrullinated peptide-negative rheumatoid arthritis. Arthritis Rheumatol (2016) 68(7):1603-13. doi:10.1002/art.39619

66. Anaya JM, Shoenfeld Y, Cervera R. Systemic lupus erythematosus 2014. Autoimmune Dis (2014) 2014:274323. doi:10.1155/2014/274323

67. Jacobi AM, Rohde W, Ventz M, Riemekasten G, Burmester GR, Hiepe F. Enhanced serum prolactin (PRL) in patients with systemic lupus erythematosus: PRL levels are related to the disease activity. Lupus (2001) 10(8):554-61. doi:10.1191/096120301701549688

68. Pacilio M, Migliaresi S, Meli R, Ambrosone L, Bigliardo B, Di Carlo R. Elevated bioactive prolactin levels in systemic lupus erythematosus - association with disease activity. J Rheumatol (2001) 28(10):2216-21.

69. Cardenas-Mondragon G, Ulloa-Aguirre A, Isordia-Salas I, Goffin V, Leanos-Miranda A. Elevated serum bioactive prolactin concentrations in patients with systemic lupus erythematosus are associated with disease activity as disclosed by homologous receptor bioassays. J Rheumatol (2007) 34(7):1514-21.

70. Leanos-Miranda A, Cardenas-Mondragon G. Serum free prolactin concentrations in patients with systemic lupus erythematosus are associated with lupus activity. Rheumatology (Oxford) (2006) 45(1):97-101. doi:10.1093/ rheumatology/kei115

71. Orbach H, Zandman-Goddard G, Boaz M, Agmon-Levin N, Amital H, Szekanecz Z, et al. Prolactin and autoimmunity: hyperprolactinemia correlates with serositis and anemia in SLE patients. Clin Rev Allergy Immunol (2012) 42(2):189-98. doi:10.1007/s12016-011-8256-0

72. Saha S, Tieng A, Pepeljugoski KP, Zandamn-Goddard G, Peeva E. Prolactin, systemic lupus erythematosus, and autoreactive B cells: lessons learnt from murine models. Clin Rev Allergy Immunol (2011) 40(1):8-15. doi:10.1007/ s12016-009-8182-6

73. Jara LJ, Pacheco-Reyes H, Medina G, Angeles U, Cruz-Cruz P, Saavedra MA. Prolactin levels are associated with lupus activity, lupus anticoagulant, and poor outcome in pregnancy. Ann N Y Acad Sci (2007) 1108:218-26. doi:10.1196/annals.1422.024

74. Leanos A, Pascoe D, Fraga A, Blanco-Favela F. Anti-prolactin autoantibodies in systemic lupus erythematosus patients with associated hyperprolactinemia. Lupus (1998) 7(6):398-403. doi:10.1191/096120398678920280

75. Leanos-Miranda A, Cardenas-Mondragon G, Ulloa-Aguirre A, Isordia-Salas I, Parra A, Ramirez-Peredo J. Anti-prolactin autoantibodies in pregnant women with systemic lupus erythematosus: maternal and fetal outcome. Lupus (2007) 16(5):342-9. doi:10.1177/0961203307078197

76. Yang XY, Liang LQ, Xu HS, He M, Yao SZ, Zhan ZP, et al. [Efficacy of oral bromocriptine in protecting the postpartum systemic lupus erythematosus patients from disease relapse]. Zhonghua Nei Ke Za Zhi (2003) 42(9):621-4.

77. Qian Q, Liuqin L, Hao L, Shiwen Y, Zhongping Z, Dongying C, et al. The effects of bromocriptine on preventing postpartum flare in systemic lupus erythematosus patients from South China. JImmunol Res (2015) 2015:316965. doi:10.1155/2015/316965

78. Praprotnik S, Agmon-Levin N, Porat-Katz BS, Blank M, Meroni PL, Cervera $\mathrm{R}$, et al. Prolactin's role in the pathogenesis of the antiphospholipid syndrome. Lupus (2010) 19(13):1515-9. doi:10.1177/0961203310373781

79. Wallaschofski H, Kobsar A, Sokolova O, Eigenthaler M, Lohmann T. Co-activation of platelets by prolactin or leptin - pathophysiological findings and clinical implications. Horm Metab Res (2004) 36(1):1-6. doi:10.1055/s-2004-814200

80. Raaz D, Wallaschofski H, Stumpf C, Yilmaz A, Cicha I, Klinghammer L, et al. Increased prolactin in acute coronary syndromes as putative co-activator of ADP-stimulated P-selectin expression. Horm Metab Res (2006) 38(11):767-72. doi:10.1055/s-2006-955090

81. Wallaschofski H, Lohmann T, Hild E, Kobsar A, Siegemund A, Spilcke-Liss $\mathrm{E}$, et al. Enhanced platelet activation by prolactin in patients with ischemic stroke. Thromb Haemost (2006) 96(1):38-44. doi:10.1160/th05-09-0634

82. Jennette JC, Falk RJ, Bacon PA, Basu N, Cid MC, Ferrario F, et al. 2012 revised International Chapel Hill Consensus Conference Nomenclature of Vasculitides. Arthritis Rheum (2013) 65(1):1-11. doi:10.1002/art.37715

83. Barrett JH, Brennan P, Fiddler M, Silman A. Breast-feeding and postpartum relapse in women with rheumatoid and inflammatory arthritis. Arthritis Rheum (2000) 43(5):1010-5. doi:10.1002/1529-0131(200005)43: 5<1010:aid-anr8>3.0.co;2-o

84. Olsen NJ, Kovacs WJ. Hormones, pregnancy, and rheumatoid arthritis. J Gend Specif Med (2002) 5(4):28-37.
85. Karlson EW, Mandl LA, Hankinson SE, Grodstein F. Do breast-feeding and other reproductive factors influence future risk of rheumatoid arthritis? Results from the Nurses' Health Study. Arthritis Rheum (2004) 50(11):345867. doi:10.1002/art.20621

86. Whyte A, Williams RO. Bromocriptine suppresses postpartum exacerbation of collagen-induced arthritis. Arthritis Rheum (1988) 31(7):927-8. doi:10.1002/art.1780310717

87. Figueroa F, Carrion F, Martinez ME, Rivero S, Mamani I, Gonzalez G. [Effects of bromocriptine in patients with active rheumatoid arthritis]. Rev Med Chil (1998) 126(1):33-41.

88. Salesi M, Sadeghihaddadzavareh S, Nasri P, Namdarigharaghani N, Farajzadegan Z, Hajalikhani M. The role of bromocriptine in the treatment of patients with active rheumatoid arthritis. Int J Rheum Dis (2013) 16(6):662-6. doi:10.1111/1756-185x.12015

89. McMurray R, Keisler D, Kanuckel K, Izui S, Walker SE. Prolactin influences autoimmune disease activity in the female B/W mouse. JImmunol (1991) 147(11):3780-7.

90. Elhai M, Avouac J, Kahan A, Allanore Y. Systemic sclerosis: recent insights. Joint Bone Spine (2015) 82(3):148-53. doi:10.1016/j.jbspin.2014.10.010

91. Jara LJ, Medina G, Saavedra MA, Vera-Lastra O, Navarro C. Prolactin and autoimmunity. Clin Rev Allergy Immunol (2011) 40(1):50-9. doi:10.1007/ s12016-009-8185-3

92. Straub RH, Zeuner M, Lock G, Scholmerich J, Lang B. High prolactin and low dehydroepiandrosterone sulphate serum levels in patients with severe systemic sclerosis. Br J Rheumatol (1997) 36(4):426-32. doi:10.1093/ rheumatology/36.4.426

93. La Montagna G, Baruffo A, Pasquali D, Bellastella A, Tirri G, Sinisi AA. Assessment of pituitary gonadotropin release to gonadotropin releasing hormone/thyroid-stimulating hormone stimulation in women with systemic sclerosis. Rheumatology (Oxford) (2001) 40(3):310-4. doi:10.1093/ rheumatology/40.3.310

94. Shahin AA, Abdoh S, Abdelrazik M. Prolactin and thyroid hormones in patients with systemic sclerosis: correlations with disease manifestations and activity. Z Rheumatol (2002) 61(6):703-9. doi:10.1007/s00393-002-0413-7

95. Vera-Lastra O, Jara LJ, Medina G, Rojas JL, Velaquez F, Ariza R, et al. Functional hyperprolactinemia and hypophyseal microadenoma in systemic sclerosis. J Rheumatol (2006) 33(6):1108-12.

96. Rueda de Leon Aguirre A, Ramirez Calvo JA, Rodriguez Reyna TS. Comprehensive approach to systemic sclerosis patients during pregnancy. Reumatol Clin (2015) 11(2):99-107. doi:10.1016/j.reuma.2014.06.006

97. Tincani A, Dall'Ara F, Lazzaroni MG, Reggia R, Andreoli L. Pregnancy in patients with autoimmune disease: a reality in 2016. Autoimmun Rev (2016) 15(10):975-7. doi:10.1016/j.autrev.2016.07.017

98. Taraborelli M, Ramoni V, Brucato A, Airo P, Bajocchi G, Bellisai F, et al. Brief report: successful pregnancies but a higher risk of preterm births in patients with systemic sclerosis: an Italian multicenter study. Arthritis Rheum (2012) 64(6):1970-7. doi:10.1002/art.34350

99. de Carvalho JF, Pereira RM, Shoenfeld Y. Pearls in autoimmunity. Auto Immun Highlights (2011) 2(1):1-4. doi:10.1007/s13317-011-0016-x

100. Belbasis L, Bellou V, Evangelou E, Ioannidis JP, Tzoulaki I. Environmental risk factors and multiple sclerosis: an umbrella review of systematic reviews and meta-analyses. Lancet Neurol (2015) 14(3):263-73. doi:10.1016/ s1474-4422(14)70267-4

101. Steinman L. Immunology of relapse and remission in multiple sclerosis. Annu Rev Immunol (2014) 32:257-81. doi:10.1146/annurev-immunol032713-120227

102. Azar ST, Yamout B. Prolactin secretion is increased in patients with multiple sclerosis. Endocr Res (1999) 25(2):207-14. doi:10.1080/07435809909066142

103. Correale J, Farez MF, Ysrraelit MC. Role of prolactin in B cell regulation in multiple sclerosis. J Neuroimmunol (2014) 269(1-2):76-86. doi:10.1016/j. jneuroim.2014.02.007

104. Zhornitsky S, Yong VW, Weiss S, Metz LM. Prolactin in multiple sclerosis. Mult Scler (2013) 19(1):15-23. doi:10.1177/1352458512458555

105. Costanza M, Binart N, Steinman L, Pedotti R. Prolactin: a versatile regulator of inflammation and autoimmune pathology. Autoimmun Rev (2015) 14(3):223-30. doi:10.1016/j.autrev.2014.11.005

106. Costanza M, Pedotti R. Prolactin: friend or foe in central nervous system autoimmune inflammation? Int J Mol Sci (2016) 17(12):2026. doi:10.3390/ ijms17122026 
107. Hellwig K, Haghikia A, Rockhoff M, Gold R. Multiple sclerosis and pregnancy: experience from a nationwide database in Germany. Ther Adv Neurol Disord (2012) 5(5):247-53. doi:10.1177/1756285612453192

108. Langer-Gould A, Huang SM, Gupta R, Leimpeter AD, Greenwood E, Albers $\mathrm{KB}$, et al. Exclusive breastfeeding and the risk of postpartum relapses in women with multiple sclerosis. Arch Neurol (2009) 66(8):958-63. doi:10.1001/archneurol.2009.132

109. Hellwig K, Rockhoff M, Herbstritt S, Borisow N, Haghikia A, Elias-Hamp $\mathrm{B}$, et al. Exclusive breastfeeding and the effect on postpartum multiple sclerosis relapses. JAMA Neurol (2015) 72(10):1132-8. doi:10.1001/ jamaneurol.2015.1806

110. Langer-Gould A, Gupta R, Huang S, Hagan A, Atkuri K, Leimpeter AD, et al. Interferon-gamma-producing $\mathrm{T}$ cells, pregnancy, and postpartum relapses of multiple sclerosis. Arch Neurol (2010) 67(1):51-7. doi:10.1001/ archneurol.2009.304

111. Parra-Medina R, Molano-Gonzalez N, Rojas-Villarraga A, Agmon-Levin N, Arango MT, Shoenfeld Y, et al. Prevalence of celiac disease in latin america: a systematic review and meta-regression. PLoS One (2015) 10(5):e0124040. doi:10.1371/journal.pone.0124040

112. Delvecchio M, Faienza MF, Lonero A, Rutigliano V, Francavilla R, Cavallo L. Prolactin may be increased in newly diagnosed celiac children and adolescents and decreases after 6 months of gluten-free diet. Horm Res Paediatr (2014) 81(5):309-13. doi:10.1159/000357064

113. Dong YH, Fu DG. Autoimmune thyroid disease: mechanism, genetics and current knowledge. Eur Rev Med Pharmacol Sci (2014) 18(23):3611-8.

114. Yamamoto M, Iguchi G, Takeno R, Okimura Y, Sano T, Takahashi M, et al. Adult combined GH, prolactin, and TSH deficiency associated with circulating PIT-1 antibody in humans. J Clin Invest (2011) 121(1):113-9. doi:10.1172/jci44073

115. Arany Z. Understanding peripartum cardiomyopathy. Annu Rev Med (2017) 69:1.1-1.12. doi:10.1146/annurev-med-041316-090545

116. Hilfiker-Kleiner D, Sliwa K. Pathophysiology and epidemiology of peripartum cardiomyopathy. Nat Rev Cardiol (2014) 11(6):364-70. doi:10.1038/ nrcardio. 2014.37

117. Haghikia A, Podewski E, Libhaber E, Labidi S, Fischer D, Roentgen P, et al. Phenotyping and outcome on contemporary management in a German cohort of patients with peripartum cardiomyopathy. Basic Res Cardiol (2013) 108(4):366. doi:10.1007/s00395-013-0366-9

118. Karaye KM, Henein MY. Peripartum cardiomyopathy: a review article. Int J Cardiol (2013) 164(1):33-8. doi:10.1016/j.ijcard.2011.11.069
119. Haghikia A, Kaya Z, Schwab J, Westenfeld R, Ehlermann P, Bachelier K, et al. Evidence of autoantibodies against cardiac troponin I and sarcomeric myosin in peripartum cardiomyopathy. Basic Res Cardiol (2015) 110(6):60. doi:10.1007/s00395-015-0517-2

120. Ansari AA, Fett JD, Carraway RE, Mayne AE, Onlamoon N, Sundstrom JB. Autoimmune mechanisms as the basis for human peripartum cardiomyopathy. Clin Rev Allergy Immunol (2002) 23:301-24. doi:10.1385/CRIAI: 23:3:301

121. Sundstrom JB, Fett JD, Carraway RD, Ansari AA. Is peripartum cardiomyopathy an organ-specific autoimmune disease? Autoimmun Rev (2002) 1(1-2):73-7. doi:10.1016/S1568-9972(01)00009-X

122. Melo MA, Carvalho JS, Feitosa FE, Araujo Junior E, Peixoto AB, Costa Carvalho FH, et al. Peripartum cardiomyopathy treatment with dopamine agonist and subsequent pregnancy with a satisfactory outcome. Rev Bras Ginecol Obstet (2016) 38(6):308-13. doi:10.1055/s-0036-1584567

123. Arrigo M, Blet A, Mebazaa A. Bromocriptine for the treatment of peripartum cardiomyopathy: welcome on BOARD. Eur Heart J (2017) 38(35):2680-2. doi:10.1093/eurheartj/ehx428

124. Horn P, Saeed D, Akhyari P, Hilfiker-Kleiner D, Kelm M, Westenfeld R. Complete recovery of fulminant peripartum cardiomyopathy on mechanical circulatory support combined with high-dose bromocriptine therapy. ESC Heart Fail (2017) 4:641-4. doi:10.1002/ehf2.12175

125. Sliwa K, Hilfiker-Kleiner D, Petrie MC, Mebazaa A, Pieske B, Buchmann $\mathrm{E}$, et al. Current state of knowledge on aetiology, diagnosis, management, and therapy of peripartum cardiomyopathy: a position statement from the Heart Failure Association of the European Society of Cardiology Working Group on peripartum cardiomyopathy. Eur J Heart Fail (2010) 12(8):767-78. doi:10.1093/eurjhf/hfq120

Conflict of Interest Statement: The authors declare that the research was conducted in the absence of any commercial or financial relationships that could be construed as a potential conflict of interest.

Copyright (c) 2018 Borba, Zandman-Goddard and Shoenfeld. This is an open-access article distributed under the terms of the Creative Commons Attribution License (CC $B Y)$. The use, distribution or reproduction in other forums is permitted, provided the original author(s) and the copyright owner are credited and that the original publication in this journal is cited, in accordance with accepted academic practice. No use, distribution or reproduction is permitted which does not comply with these terms. 